\title{
Profitabilitas sebagai Pemoderasi Pengaruh Pertumbuhan Perusahaan pada Nilai Perusahaan
}

\author{
Dewa Putu Dharmayusa1 \\ Fakultas Ekonomi dan Bisnis \\ Universitas Udayana, Indonesia
}

\author{
I Gusti Ngurah Agung Suaryana ${ }^{2}$ \\ Fakultas Ekonomi dan Bisnis \\ Universitas Udayana, Indonesia
}

Surel : dewadharmayusa30@gmail.com

\section{ABSTRAK}

Penelitian ini bertujuan untuk memperoleh bukti empiris pengaruh pertumbuhan perusahaan pada nilai perusahaan dengan profitabilitas sebagai pemoderasi Penelitian ini dilakukan pada perusahaan manufaktur sektor consumer goods yang terdaftar di BEI. Sampel ditentukan melalui metode non probability sampling dengan teknik purposive sampling. Jumlah pegamatan yang diperoleh dalam penelitian ini adalah sebanyak 60 data amatan selama periode pengamatan 2015-2017. Teknik analisis data yang digunakan adalah Moderated Regression Analysis (MRA). Hasil dari penelitian ini menunjukkan bahwa pertumbuhan perusahaan dan profitabilitas tidak berpengaruh pada nilai perusahaan. Profitabilitas tidak mampu memoderasi pengaruh pertumbuhan perusahaan pada nilai perusahaan.

Kata Kunci: Nilai Perusahaan; Pertumbuhan Perusahaan; Profitabilitas.

\section{Profitability as Moderator Variable of Companies Growth to Companies Value}

\section{ABSTRACT}

This study aims to prove empirically the effect of companies growth to companies value with profitability as moderating. This study done at manufacturing companies in consumer goods sector that listed on the IDX. Sample were selected using with non-probability sampling method with purposive sampling technique. Total observation on this study is 60 observations for period 2015-2017. Analysis technique that used is Moderated Regression Analysis (MRA). The result of this study show companies growth and profitability doesn't affect companies value. Profitability didn't capable to moderating companies growth in affecting companies value.

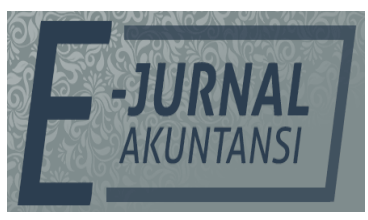

e-ISSN 2302-8556

Vol. 31 No. 10

Denpasar, Oktober 2021 Hal. 2597-2607

DOI:

10.24843/EJA.2021.v31.i10.p15

PENGUTIPAN:

Dharmayusa, D.P., \& Suaryana, I.G.N.A. (2021).

Profitabilitas sebagai

Pemoderasi Pengaruh Pertumbuhan Perusahaan pada Nilai Perusahaan. EJurnal Akuntansi, 31(10), $2597-2607$

RIWAYAT ARTIKEL: Artikel Masuk: 5 November 2020 Artikel Diterima: 23 Maret 2021

Keywords: $\quad$ Companies Value; Companies Growth; Profitability.

Artikel dapat diakses : https://ojs.unud.ac.id/index.php/Akuntansi/index 


\section{PENDAHULUAN}

Perusahaan memilik tujuan utama yaitu untuk meningkatkan nilai perusahaan. Nilai perusahaan merupakan persepsi investor mengenai keberhasilan suatu perusahaan dalam mengelola perusahaannya. Nilai perusahaan dapat dicerminkan melalui harga sahamnya. Harga saham terbentuk dari permintaan dan penawaran yang merefleksikan penilaian investor pada perusahaan. Investor dapat mempergunakan nilai perusahaan sebagai acuan melihat bagaimana kinerja perusahaan di masa depan. Terdapat berbagai cara bagi investor dalam menilai suatu perusahaan. Diantaranya dengan menggunakan Tobin's Q, Earrning Per Share (EPS) dan Price to Book Value (PBV).

Tabel 1. Nilai Perusahaan Sektor Consumer Goods Periode 2015-2017 (Perhitungan Berdasarkan Rumus Tobin's Q)

\begin{tabular}{cccc}
\hline \multirow{2}{*}{ Kode Perusahaan } & \multicolumn{3}{c}{ Tahun } \\
\cline { 2 - 4 } & 2015 & 2016 & 2017 \\
\hline ADES & 1,4139 & 1,2678 & 1,1179 \\
AISA & 0,9920 & 1,2157 & 0,7853 \\
ALTO & 1,1724 & 1,2065 & 1,3883 \\
CEKA & 0,8396 & 0,9406 & 0,9027 \\
DLTA & 4,1915 & 3,4970 & 2,8872 \\
DVLA & 1,3467 & 1,5739 & 1,6526 \\
GGRM & 2,0679 & 2,3246 & 2,7833 \\
HMSP & 11,6638 & 10,6763 & 12,9624 \\
ICBP & 3,3413 & 3,8199 & 3,6397 \\
INAF & 0,9530 & 11,1456 & 12,6073 \\
\hline
\end{tabular}

Sumber: www.idx.co.id, 2018

Tabel 1, menunjukkan nilai perusahaan-perusahaan sektor consumer goods yang terdaftar di BEI selama periode 2015-2017 dengan menggunakan rumus Tobin's Q. Melalui Tabel 1, dapat dilihat bahwa terjadi kenaikan dan penurunan nilai perusahaan selama periode 2015-2017. Kenaikan dan penurunan ini bisa disebabkan oleh faktor-faktor tertentu. Dapat dikatakan bahwa kenaikan dan penurunan nilai perusahaan merupakan hasil dari pertumbuhan suatu perusahaan. Gustian (2017), Izza (2013), Lasmita et al. (2016), Armika (2018) dan Santi (2007) dalam penelitian mereka mengemukakan secara empiris bahwa pertumbuhan perusahaan tersebut mempengaruhi nilai perusahaan.

Dhani (2017) dalam penelitiannya untuk megetahui hubungan antara pertumbuhan perusahaan dengan nilai perusahaan mendapatkan hasil bahwa pertumbuhan perusahaan memilik pengaruh yang positif pada nilai perusahaan. Penelitian yang dilakukan oleh Gustian (2017), Lasmita (2016), dan Rostiawati (2015) mendapatkan hasil yang serupa. Sedangkan hasil yang berbeda di dapat dari beberapa penelitian serupa, Suwardika (2017) menyatakan bahwa pertumbuhan perusahaan memberikan pengaruh yang negatif pada nilai perusahaan. Hasil serupa juga didapatkan dari penelitian yang dilakukan oleh Izza (2013), Armika (2018), dan Santi (2007).

Ketidakkonsistenan tersebut mungkin terjadi karena terdapat faktor lain yang mempengaruhi hubungan pertumbuhan perusahaan dengan nilai perusahaan. Sumiati (2013) menyatakan bahwa dalam mepertahankan usahanya, 
profitabilitas bagi perusahaan merupakan hal yang sangat penting. Dalam beberapa penelitian terdahulu seperti penelitian oleh Atmaja (2018) mengenai pengaruh profitabilitas pada nilai perusahaan mendapatkan hasil bahwa perusahaan yang memiliki profitabilitas tinggi cenderung terjadi peningkatan nilai perusahaannya. Hasil serupa juga di dapat dari hasil penelitian oleh Armika (2018) dan Mahatma (2013). Penelitian terdahulu yang mengalami ketidakonsistenan hasil pengaruh pertumbuhan perusahaan dengan nilai perusahaan. Hal tersebut yang di asumsikan karena faktor lain mempengaruhi hubungan tersebut. Berdasarkan teori sinyal profitabilitas dapat memperkuat pengaruh pertumbuhan perusahaan pada nilai perusahaan.

Pihak pemilik informasi berusaha memberikan informasi dengan cara memberikan suatu sinyal yang dapat dimanfaatkan oleh pihak penerima informasi. Pihak penerima akan menyesuaikan perilakunya sesuai dengan pemahamannya terhadap teori sinyal. Informasi yang dipublikasikan sebagai suatu pengumuman akan memberikan sinyal bagi investor dalam pengambilan keputusan investasi. Jika pengumuman tersebut mengandung nilai positif, maka pasar akan bereaksi pada saat pasar emenerima informasi tersebut. Pelaku pasar akan menginterprestasikan informasi tersebut sebagai sinyal baik atau sinyal buruk. Putra (2018) menyatakan bahwa berdasarkan sinyal yang diberikan akan terjadi perubahan dalam volume perdagangan saham.

Profitabilitas adalah kemampuan perusahaan dalam mengelola sumber daya perusahaan dalam mendapatkan laba. Gitman \& Zutter (2015) mengatakan profitabilitas merupakan kemampuan perusahaan dalam memeroleh keuntungan yang berhubungan dengan tingkat pejualan, total aset, ataupun modal sendiri. Perusahaan dengan profitabilitas tinggi menunjukan kinerja perusahaannya bagus. Pertumbuhan perusahaan merupakan kemampuan perusahaan untuk meningkatkan size. Perusahaan dengan pertumbuhan aset yang baik adalah perusahaan yang mampu untuk mengelola sumberdaya untuk mengahasilkan keuntungan sehingga dapat menambah aset yang telah dimiliki. Pertumbuhan perusahaan sangat diharapkan oleh banyak pihak baik internal maupun eksternal, karena pertumbuhan yang baik memberi tanda bagi perkembangan perusahaan. Pertumbuhan suatu perusahaan merupakan tanda perusahaan memiliki aspek yang menguntungkan, karena dianggap mampu menghasilkan keuntungan yang lebih baik dari waktu ke waktu.

Nilai perusahaan merupakan nilai yang dimiliki perusahaan yang tercermin dari indikator harga saham perusahaan. Tujuan perusahaan dalam jangka panjang adalah mengoptimalkan nilai perusahaan dengan meminimalkan biaya modal perusahaan. Kusumajaya (2011) mengemukakan semakin tinggi nilai perusahaan menggambarkan semakin sejahterahnya pemilik perusahaan.

Teori sinyal menyatakan bahwa semakin tinggi pertumbuhan yang dialami oleh suatu perusahaan maka akan memberikan sinyal positif kepada investor. Pertumbuhan perusahaan yang dicerminkan dari pertumbuhan aset memberikan sinyal bahwa perusahaan mampu mengelola sumberdaya yang ada untuk mengahasilkan keuntungan sehingga dapat menambah aset yang telah dimiliki. Kinerja perusahaan yang baik akan mengakibatkan naiknya permintaan investor untuk membeli saham perusahaan dan akhirnya meningkatkan nilai perusahaan. 
Berdasarkan teori yang telah dipaparkan maka kerangka konseptual dari penelitian ini adalah sebagai berikut.

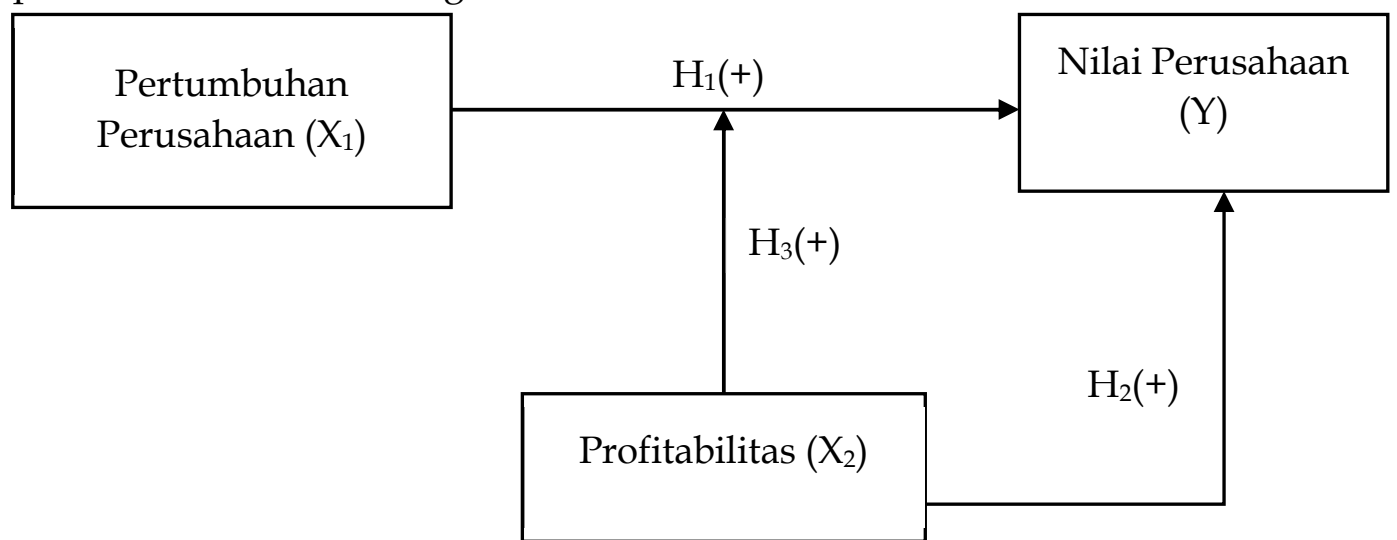

\section{Gambar 1. Kerangka Konseptual Penelitian}

Sumber: Data Penelitian, 2019

Penelitian terdahulu yang telah dilakukan oleh Dhani (2017), Gustian (2017), dan Suastini (2016) mendukung konsep dari teori sinyal yang mengemukakan bahwa bahwa pertumbuhan perusahaan merupakan suatu aspek positif yang berdampak pada peningkatan nilai perusahaan. Dhani (2017) menyatakan bahwa perusahaan dengan pertumbuhan aset yang baik adalah perusahaan yang mampu untuk mengelola sumberdaya untuk mengahasilkan keuntungan sehingga dapat menambah aset yang telah dimiliki. Gustian (2017) mengemukakan bahwa jika dilihat dari sudut pandang investor, perusahaan yang memiliki pertumbuhan yang baik akan menghasilkan tingkat pengembalian (rate of return) yang baik dari investasi yang dilakukannya. Suastini (2016) menyatakan bahwa pertumbuhan perusahaan merupakan suatu aspek positif yang diharapkan berdampak pada peningkatan nilai perusahaan.

$\mathrm{H}_{1}$ : Pertumbuhan perusahaan berpengaruh positif pada nilai perusahaan.

Teori sinyal menyatakan bahwa bila perusahaan memiliki nilai profitabilitas yang tinggi akan memberikan sinyal positif kepada investor. Investor berinvestasi dengan tujuan medapatkan keuntungan. Perusahaan dengan profitabilitas tinggi mencerminkan perusahaan berhasil mengelola sumber daya untuk mencapai keuntungan. Profitabilitas yang tinggi meningkatkan minat investor dalam berinvestasi dalam perusahaan. Penelitian terdahulu yang telah dilakukan oleh Atmaja (2018), Armika 2018, dan Mahatma (2013) mendukung konsep dari teori sinyal yang mengemukakan bahwa profitabilitas merupakan faktor yang berpengaruh positif pada perubahan yang terjadi pada nilai perusahaan.

$\mathrm{H}_{2}$ : Profitabilitas berpengaruh positif pada nilai perusahaan.

Teori sinyal menyatakan bahwa pertumbuhan perusahaan akan akan memberikan sinyal positif pada investor. Pertumbuhan perusahaan yang semakin tinggi menandakan kemampuan perusahaan dalam menjalankan kegiatan operasionalnya semakin baik karena mampu menambah aset yang sudah ada. Selain melaui pertumbuhan kinerja perusahaan dapat dilihat melalui kemampuan mendapatkan laba. Tingkat profitabilitas suatu perusahaan menunjukan kemampuan perusahaan dalam mendapatkan laba. Tingkat profitabilitas akan memberikan sinyal positif terkait kinerja perusahaan pada investor. Perusahaan 
yang memiliki tingkat pertumbuhan yang tinggi dan memiliki tingkat profitabilitas yang tinggi akan memberikan sinyal positif yang lebih dibandingkan dengan perusahaan yang memiliki tingkat pertumbuhan tapi profitabilitasnya rendah.

$\mathrm{H}_{3}$ : Profitabilitas memperkuat pengaruh pertumbuhan perusahaan pada nilai perusahaan.

\section{METODE PENELITIAN}

Penelitian dilakukan pada perusahaan sektor manufaktur yang terdaftar di Bursa Efek Indonesia periode 2015-2017 yang dapat diakses melalui www.idx.co.id. Data yang didapat berbentuk Indonesia Capital Market Directory (ICMD). Objek penelitian yang digunakan dalam penelitian ini ialah profitabilitas, pertumbuhan perusahaan dan nilai perusahaan pada perusahaan manufaktur yang terdaftar di bursa efek Indonesia selama periode 2015-2017. Variabel dependen dalam penelitian ini adalah nilai perusahaan. Variabel independen dalam penelitian ini adalah pertumbuhan perusahaan. Variabel moderasi dalam penelitian ini adalah profitabilitas yang mempengaruhi pertumbuhan perusahaan pada nilai perusahaan.

Pertumbuhan perusahaan menggambarrkan perkembangaan perusahaan yang terjadi. Pertumbuhan perusahaan dapat dilihat berdasarkan pertumbuhan asetnya. Pertumbuhan dalam aset perusahaan dapat diartikan sebagai perusahaan atau tingkat pertumbuhan tahunan dari aset total perusahaan sebelumnya ke tahun selanjutnya. Pengukuran pertumbuhan aset dapat diukur menggunakan rasio asset growth (AG) yang dirumuskan sebegai berikut.

$A G=\frac{\text { Total asset }_{t}+\text { Total asset }_{t-1}}{\text { Total asset }_{t-1}}$

Keterangan:

AG : Asset Growth

Total asset $\mathrm{t}_{\mathrm{t}} \quad$ : Total aset tahun berjalan

Total asset $\mathrm{t}-1$ : Total aset tahun sebelumnya

Profitabilitas merupakan salah satu pengukuran bagi kinerja suatu perusahaan. Profitabilitas adalah ukuran kemampuan perusahaan perseorangan atau badan untuk menghasilkan laba dengan memperhatikan modal yang digunakan. Dalam penelitian ini rasio profitabilitas yang digunakan yaitu Return On Asset (ROA). ROA digunakan karena dapat memberikan pengukuran yang memadai atas seluruh efektifitas perusahaan dan dapat mewakili nilai profitabilitas. ROA sebagai proxy dari profitabilitas memiliki rumus sebagai berikut:

ROA $=\frac{\text { Laba }(\text { Rugi }) \text { Setelah Pajak }}{\text { Total Aset }} \times 100 \%$

Nilai perusahaan merupakan pandangan investor pada perusahaan dalam mengelola sumber daya pada tahun berjalan. Pada penelitian ini nilai perusahaan diwakili dengan Tobin's Q. Pengukuran nilai perusahaan dengan menggunakan Tobin's Q selain memberikan gambaran pada aspek fundamental, juga sejauh mana pasar menilai perusahaan dari berbagai aspek yang dilihat oleh pihak luar termasuk investor. Tobin's $Q$ mewakili sejumlah variabel penting penting dalam pengukuran kinerja, antara lain aktiva tercatat perusahaan, kecenderungan pasar yang memadai seperti pandangan analis mengenai prospek perusahaan, dan 
variabel modal intelektual atau intangiable asset. Tobin's $Q$ dapat di formulasikan sebagai berikut.

$Q=\frac{M V E+D E B T}{T A}$

Keterangan:

Q : Nilai perusahaan

MVE : Nilai pasar ekuitas (jumlah saham beredar $\times$ closing price)

DEBT : Total kewajiban

Populasi yang digunakan dalam penelitian ini adalah seluruh perusahaan manufktur yang terdaftar di Bursa Efek Indonesia periode 2015-2017. Peneliti menggunakan sektor manufaktur karena memiliki jumlah perusahaan lebih dibandingkan dengan sektor lainnya di Indonesia (Damayanti \& Suartana 2014). Sampel dari penelitian ini merupakan perusahaan manufaktur subsektor consumer goods. Subsektor ini dipilih karena memiliki pergerakan harga saham terbesar dibanding yang lain. Keterangan tersebut didapat berdasarkan indeks harga saham dari BEI. Metode pengumpulan sampel yang digunakan dalam penelitian ini ialah metode non-probability sampling dengan teknik purposive sampling. Kriteriakriteria yang harus terpenuhi dalam pengambilan sampel dengan teknik purposive sampling sebagai berikut Perusahaan listed selama periode penelitian, Memilik nilai aset di atas 500 milyar rupiah, Laporan keuangan dengan mata uang rupiah.

Jenis data yang digunakan adalah data kuantitatif, data kuantitatif dalam penelitian ini meliputi laporan keuangan masing-masing perusahaan manufaktur yang terdaftar pada Bursa Efek Indonesia periode 2015-2017. Sumber data dalam penelitian ini adalah data sekunder, data sekunder dalam penelitian ini berupa laporan keuangan tahunan masing-masing perusahaan manufaktur yang terdaftar di Burse Efek Indonesia periode 2015-2017 yang diperoleh dari situs www.idx.co.id. Metode pengumpulan data yang digunakan dalam penelitian ini adalah dokumentasi dan observasi non-partisipan. Teknik analisis data yang digunakan dalam penelitian ini adalah Moderate Regression Analysis (MRA). Analisis regresi liier berganda digunakan untuk mengetahui hubungan antara variabel profitabilitas, pertumbuhan perusahaan dan nilai perusahaan. MRA digunakan untuk mengetahui profitabilitas dalam memoderasi pengaruh pertumbuhan perusahaan pada nilai perusahaan. Persamaa MRA yaitu sebagai berikut.

$Y=\alpha+\beta_{1} X_{1}+\beta_{2} X_{2}+\beta_{3} X_{1} X_{2}+\varepsilon$

Keterangan:

$\begin{array}{ll}\mathrm{Y} & : \text { Nilai perusahaan } \\ \mathrm{a} & : \text { Konstanta } \\ \beta_{1-3} & : \text { Koefisien regresi } \\ \mathrm{X}_{1} & : \text { Pertumbuhan perusahaan } \\ \mathrm{X}_{2} & : \text { Profitabilitas } \\ \mathrm{X}_{1} \mathrm{X}_{2} & : \text { Interaksi pertumbuhan perusahaan dengan profitabilitas } \\ \varepsilon & : \text { Error }\end{array}$

\section{HASIL DAN PEMBAHASAN}

Sampel yang digunakan dalam penelitian ini adalah sebanyak 20 perusahaan manufaktur sektor consumer goods selama tiga tahun dengan total data observasian 
sebanyak 60 data. Adapun hasil analisis sampel dengan menggunakan tekik purposive sampling dapat ditunjukkan pada Tabel 2, berikut.

Tabel 2. Proses dan Hasil Seleksi Sampel Berdasarkan Kriteria

\begin{tabular}{clcc}
\hline No. & \multicolumn{1}{c}{ Keterangan } & Jumlah & Akumulasi \\
\hline 1. & $\begin{array}{l}\text { Perusahaan sub sektor consumer goods yang terdaftar } \\
\text { di BEI periode 2015-2017 secara berturut-turut. }\end{array}$ & 34 & 102 \\
2. & $\begin{array}{l}\text { Perusahaan sub sektor consumer goods yang tidak } \\
\text { memiliki total aset lebih dari 500 milyar rupiah. }\end{array}$ & $(6)$ & $(18)$ \\
3. & $\begin{array}{l}\text { Laporan keuangan perusahaan yang tidak } \\
\text { menggunakan mata uang rupiah. }\end{array}$ & $(0)$ & $(0)$ \\
4. & $\begin{array}{l}\text { Perusahaan sub sektor consumer goods yang tidak } \\
\text { menyajikan informasi CSR di laporan tahunan. }\end{array}$ & $(0)$ & $(0)$ \\
5. Data Outlier & $(8)$ & $(24)$ \\
Jumlah observasian yang memenuhi kriteria selama periode & 20 & 60 \\
\hline
\end{tabular}

Sumber: Data Penelitian, 2019

Adanya data outlier dalam penelitian ini disebabkan karena beberapa perusahaan memiliki nilai Tobin's Q yang berbeda sangat jauh (extreme) dengan perusahaan lainnya sehingga data penelitian menjadi tidak normal. Untuk mengatasi hal ini, harus dilakukan penghilangan data-data extreme tersebut agar model yang diuji lolos sesuai dengan kriteria pengujian asumsi klasik.

Tabel 3. Statistik Deskriptif Variabel Penelitian

\begin{tabular}{cccccc}
\hline Variable & $N$ & Minimum & Maximum & Mean & Std. Deviation \\
\hline $\mathrm{X}_{1}$ & 60 & $-0,105$ & 0,620 & 0,110 & 0,136 \\
$\mathrm{X}_{2}$ & 60 & $-0,155$ & 0,377 & 0,068 & 0,102 \\
$\mathrm{Y}$ & 60 & 0,562 & 3,896 & 1,753 & 0,939 \\
\hline
\end{tabular}

Sumber: Data Penelitian, 2019

Berdasarkan hasil uji statistik deskriptif pada Tabel 3, dapat dijelaskan statistik deskriptif untuk variabel pertumbuhan perusahaan $\left(X_{1}\right)$ memiliki nilai minimum sebesar -0,105 dimiliki oleh Indofood Sukses Makmur Tbk dan nilai maksimum sebesar 0,620 dimiliki oleh PT. Sekar Bumi Tbk juga. Nilai rata-rata (mean) sebesar 0,110. Standar deviasi dari pertumbuhan perusahaan sebesar 0,136 yang berarti data nilai perusahaan cenderung homogen (mendekati nol). Variabel profitabilitas $\left(\mathrm{X}_{2}\right)$ memiliki nilai minimum dimiliki oleh Bentoel internasional investama Tbk dan nilai maksimum sebesar 0,376 dimiliki oleh HM sampoerna Tbk. Nilai rata-rata (mean) sebesar 0,068. Standar deviasi dari pertumbuhan perusahaan sebesar 0,102 yang berarti data nilai perusahaan cenderung homogen (mendekati nol). Variabel nilai perusahaan $(Y)$ memiliki nilai minimum sebesar 0,562 dimiliki oleh PT. Martina Berto Tbkdan nilai maksimum sebesar 3,8961 dimiliki oleh Nippon Indosari Corpindo Tbk. Nilai rata-rata (mean) sebesar 1,753. Standar deviasi dari nilai perusahaan sebesar 0,939 yang berarti data nilai perusahaan cenderung homogen (mendekati nol).

\section{Tabel 4. Hasil Uji Normalitas}

\begin{tabular}{cc}
\hline & Unstandardized Residual \\
\hline $\mathrm{N}$ & 60 \\
Kolmogorov-Smirnov Z & 0,146 \\
Asymp. Sig. (2-tailed) & 0,075 \\
\hline
\end{tabular}

Sumber: Data Penelitian, 2019 
Berdasarkan hasil dari Tabel 4, dapat dilihat bahwa model persamaan memiliki nilai Kolmogorov Smirnov sebesar 0,146 serta memiliki nilai signifikan bernilai 0,075. Hal ini menunjukkan bahwa model persamaan memenuhi uji normalitas karena nilai Asymp. Sig. (2-tailed) lebih besar dari 0,05.

Tabel 5. Hasil Uji Autokorelasi

\begin{tabular}{cccccc}
\hline Model & $\mathrm{R}$ & $\mathrm{R}$ Square & $\begin{array}{c}\text { Adjusted } \mathrm{R} \\
\text { Square }\end{array}$ & $\begin{array}{c}\text { Std. Error of the } \\
\text { Estimate }\end{array}$ & $\begin{array}{c}\text { Durbin- } \\
\text { Watson }\end{array}$ \\
\hline 1 & 0,502 & 0,252 & 0,212 & 0,833 & 1,757 \\
\hline
\end{tabular}

Sumber: Data Penelitian, 2019

Berdasarkan Tabel 5, dapat terlihat bahwa model regresi MRA memiliki nilai Durbin-Watson sebesar 1,757. Nilai dU untuk jumlah sampel 60 dengan 3 variabel bebas $(k)$ dengan level of significant 5 persen $(0,05)$ adalah 1,689. Maka nilai 4 -dU untuk model regresi kedua adalah 2,311. Sehingga hasil uji autokorelasinya adalah $\mathrm{dU}<\mathrm{d}<(4-\mathrm{dU})$, yaitu 1,689 < 1,757 $<2,311$. Hal ini berarti koefisien regresi model bebas dari gangguan autokorelasi.

Tabel 6. Hasil Uji Heterokedastisitas

\begin{tabular}{ccc}
\hline Model & Sig. & Keterangan \\
\hline Pertumbuhan Perusahaan $\left(\mathrm{X}_{1}\right)$ & 0,054 & Bebas Heteroskedastisitas \\
Profitabilitas $\left(\mathrm{X}_{2}\right)$ & 0,075 & Bebas Heteroskedastisitas \\
Interaksi $\left(\mathrm{X}_{1} \mathrm{X}_{2}\right)$ & 0,541 & Bebas Heteroskedastisitas \\
\hline
\end{tabular}

Sumber: Data Penelitian, 2019

Berdasarkan Tabel 6, terlihat nilai signifikansi model regresi memiliki nilai melebihi 0,05. Hal ini menunjukkan bahwa kedua model regresi tersebut bebas dari gejala heterokedastisitas.

Tabel 7. Hasil Uji Moderated Regression Analysis

\begin{tabular}{ccccc}
\hline \multirow{2}{*}{ Variabel } & \multicolumn{2}{c}{ Unstandardized Coefficient } & Standardized Coefficient & \multirow{2}{*}{ Sig. } \\
\cline { 2 - 4 } & $\mathrm{B}$ & Std. Error & Beta & \\
\hline (Constant) & 1,326 & 0,155 & & 0,000 \\
$\mathrm{X}_{1}$ & 1,800 & 0,914 & 0,261 & 0,054 \\
$\mathrm{X}_{2}$ & 2,658 & 1,465 & 0,289 & 0,075 \\
$\mathrm{X}_{1} \mathrm{X}_{2}$ & 5,416 & 8,796 & 0,101 & 0,541 \\
$\mathrm{R}^{2}$ & $:$ & 0,252 & & \\
F Sig. & $:$ & 0,001 & & \\
\hline
\end{tabular}

Sumber: Data Penelitian, 2019

Adapun persamaan regresi yang dihasilkan dalam penelitian ini adalah sebagai berikut.

$$
\mathrm{Y}=1,326+1,800 \mathrm{X}_{1}+2,658 \mathrm{X}_{2}+5,416 \mathrm{X}_{1} \mathrm{X}_{2}+0,255
$$

Nilai konstanta sebesar 1,326 mempunyai arti bahwa apabila nilai variabel independen yaitu pertumbuhan perusahaan dan profitabilitas sama dengan nol, maka nilai perusahaan adalah sebesar 1,326 dengan asumsi variabel independen konstan. P-value dari pertumbuhan perusahaan $\left(X_{1}\right)$ sebesar 0,054>0,05 (tidak signifikan), dan $p$-value dari profitabilitas $\left(\mathrm{X}_{2}\right)$ sebesar 0,075>0,05 (tidak signifikan). Kedua variabel memperoleh hasil yang tidak signifikan, sehingga variabel pertumbuhan maupun profitabilitas tidak mampu menjelaskan variasi perubahan nilai perusahaan secara signifikan, pada variabel interaksi $\left(\mathrm{X}_{1} \_\mathrm{X}_{2}\right)$ memiliki $p$-value sebesar 0,541<0,05 (tidak signifikan). Hal ini berarti profitabilitas tidak mampu memoderasi pengaruh pertumbuhan perusahaan pada nilai perusahaan. Jika 
dilihat dari $p$-value pengaruh langsung profitabilitas pada nilai perusahaan dengan p-value kemampuan profitabilitas dalam memoderasi, maka dapat ditarik kesimpulan bahwa profitabilitas merupakan pemoderasi tipe homologiser moderator. Variabel profitabiltas dapat dikatakan homologiser moderator karena hasil uji interaksi antara variabel profitabilitas dengan hubungan antara variabel pertumbuhan perusahaa pada variabel nilai perusahaan memperoleh hasil yang tidak signifikan $(0,541<0,05)$ dan hubungan langsung antara variabel profitabilitas dengan variabel nilai perusahaan tidak signifikan $(0,75>0,05)$.

Hasil analisis yang terlihat pada Tabel 7, menunjukkan nilai signifikansi $\mathrm{F}$ sebesar $0,001<0,05$. Hasil tersebut menunjukkan bahwa variabel-variabel independen yaitu pertumbuhan perusahaan, profitabilitas beserta interaksinya berpengaruh pada variabel dependennya yaitu nilai perusahaan. Berdasarkan hal tersebut maka dapat disimpulkan bahwa model penelitian ini dikatakan layak untuk diteliti dan dapat dilanjutkan dengan pembuktian hipotesis. Hasil analisis yang terlihat pada Tabel 7, menunjukkan nilai $\mathrm{R}^{2}$ dari model persamaan memiliki nilai sebesar 0,252 . Ini berarti 25.2 persen variasi nilai perusahaan dapat dijelaskan oleh variabel pertumbuhan perusahaan dan profitabilitas, sedangkan 74.8 persen sisanya dijelaskan oleh faktor lain yang tidak diuji dalam model penelitian ini.

Berdasarkan Tabel 7, hasil uji statistik t menunjukkan bahwa pertumbuhan perusahaan memiliki koefisien beta sebesar 1,8 dengan nilai p-value sebesar $0,054>0,05$. Hasil pengujian ini mengindikasikan bahwa pertumbuhan perusahaan tidak berpengaruh pada nilai perusahaan, sehingga $\mathrm{H}_{0}$ diterima dan $\mathrm{H}_{1}$ ditolak. Berdasarkan Tabel 7, hasil uji statistik $t$ menunjukkan bahwa pertumbuhan perusahaan memiliki koefisien beta sebesar 2,658 dengan nilai $p$-value sebesar $0,075>0,05$. Hasil pengujian ini mengindikasikan bahwa profitabilitas tidak berpengaruh pada nilai perusahaan, sehingga $\mathrm{H}_{0}$ diterima dan $\mathrm{H}_{2}$ ditolak. Berdasarkan Tabel 7, hasil uji statistik $t$ menunjukkan bahwa interaksi pertumbuhan perusahaan dan profitabilitas memiliki koefisien beta sebesar 5,416 dengan nilai p-value sebesar 0,541 <0,05. Hasil pengujian ini mengindikasikan bahwa profitabilitas tidak mampu memoderasi hubungan pertumbuhan perusahaan pada nilai perusahaan sehingga $\mathrm{H}_{0}$ diterima dan $\mathrm{H}_{3}$ ditolak.

Hipotesis pertama $\left(\mathrm{H}_{1}\right)$ menyatakan pertumbuhan perusahaan berpengaruh positif pada nilai perusahaan. Berdasarkan Tabel 7, hasil uji statistik $t$ menunjukkan bahwa pertumbuhan perusahaan memiliki t positif sebesar 1,969 dengan nilai $p$-value sebesar $0,054>0,05$. Berdasarkan hasil uji tersebut tidak dapat membuktikan hipotesis pertama. Pertumbuhan perusahaan dalam penelitian ini menggunakan kenaikan atau penurunan total aset. Semakin tinggi kenaikan total aset belum tentu meningkatkan keinginan para investor untuk membeli saham perusahaan tersebut. Karena kenaikan dari total aset bisa dari berbagai macam faktor, baik keuntungan atau bisa bersasal dari peberbitan obligasi dan penerbitan saham baru. Sehingga masih belum pasti apakah dari kenaikan total aset berarti perusahaan mempu mengelola sumber daya yang ada untuk memperoleh laba sehingga menghasilkan kinerja yang baik. Hasil penelitian sejalan dengan penelitia yang dilakukan Izza (2013) yang menyatakan bahwa pertumbuhan perusahaan berpengaruh nilai perusahaan. Hasil serupa juga didapatkan dari penelitian yang dilakukan oleh Izza 2013, Suryani (2015), dan Puspita (2011). 
Hipotesis kedua $\left(\mathrm{H}_{2}\right)$ menyatakan profitabilitas berpengaruh positif pada nilai perusahaan. Berdasarkan Tabel 7 , hasil uji statistik $t$ menunjukkan bahwa pertumbuhan perusahaan memiliki t positif sebesar 1,814 dengan nilai $p$-value sebesar 0,074 >0,05. Berdasarkan hasil uji tersebut tidak dapat membuktikan hipotesis kedua. Profitabilitas dalam penelitian ini menggunakan ROA. ROA menunjukan bagaimana kemampuan perusahaan dalam mengelola total aset perusahaan. Aset yang dikelola perusahaan untuk mendapatkan keuntungan dengan baik akan meningkatkan keinginan investor untuk berinvestasi dalam perusahaan. Investor tidak hanya melihat keuntungan datang dari kemampuan megelola aset selain itu ada kemampuan dari pengelolaan modal dan penjualan. Sehingga pengelolaan laba saja belum tentu menunjukan bagaimana kinerja perusahaan di mata investor.

Hipotesis ketiga $\left(\mathrm{H}_{3}\right)$ menyatakan profitabilitas memoderasi pengaruh pertumbuhan perusahaan pada nilai perusahaan. Berdasarkan Tabel 4.6 hasil uji statistik $t$ menunjukkan bahwa interaksi pertumbuhan perusahaan dan pengungkapan CSR memiliki t positif sebesar 0,616 dengan nilai p-value sebesar $0,541>0,05$. Berdasarkan hasil uji tersebut tidak dapat membuktikan hipotesis ketiga. Teori sinyal menyatakan bahwa pertumbuhan perusahaan akan akan memberikan sinyal positif pada investor. Pertumbuhan perusahaan yang semakin tinggi menandakan kemampuan perusahaan dalam menjalankan kegiatan operasionalnya semakin baik karena mampu menambah aset yang sudah ada, namun penambahan aset tersebut tidak mampu memberikan sinyal terkait sustainabilitas perusahaan. Profitabilitas suatu perusahaan memberikan sinyal positif mengenai sustainibilitas perusahaan. Dengan demikian profitabilitas memperkuat pengaruh pertumbuhan perusahaan karena selain memberikan sinyal terkait kemampuan mendapatkan laba, perusahaan juga memberikan jaminan terkait sustainabilitas perusahaan di masa depan dengan kemampuan memperoleh laba yang baik. Perusahaan yang memiliki tingkat pertumbuhan tinggi dan disertai profitabilitas yang semakin baik akan memberikan sinyal positif yang lebih tinggi dibandingkan perusahaan yang memiliki tingkat pertumbuhan tinggi namun profitabilitas yang buruk.

\section{SIMPULAN}

Berdasarkan ketiga pengujian yang telah dilakukan dapat disimpulkan bahwa profitabilitas tidak memengaruhi pertumbuhan perusahaan pada nilai perusahaan, serta pertumbuhan perusahaan dan pengungkapan CSR tidak memiliki pengaruh pada nilai perusahaan secara langsung.

Penelitian ini memiliki jumlah sampel yang masih terbatas pada perusahaan consumer goods yang tergabung dalam Bursa Efek Indonesia sehingga disarankan kepada peneliti selanjutnya untuk mengambil sampel yang lebih banyak dengan menambahkan periode tahun penelitian dan juga menggunakan faktor-faktor lain yang mempengaruhi nilai perusahaan pada sektor berbeda guna mengetahui apakah hal yang sama juga berlaku pada sektor lainnya.

\section{REFERENSI}

Armika, A. A. A. M., \& Suryanawa I.K. (2018). Pengaruh Pengungkapan Tanggung Jawab Sosial Pada Nilai Perusahaan Dengan Profitabilitas Sebagai Variabel 
Pemoderasi. E-Jurnal Akuntansi 22(1): 80-107.

Atmaja, I G. N. Y. D., \& Astika, I. B. P. (2018). Pengaruh Profitabilitas, Leverage, Dan Modal Kerja Pada Nilai Perusahaan Dengan CSR Sebagai Variabel Intervening. E-Jurnal Akuntansi 24: 1.

Damayanti, N. P. W. P., \& Suartana I.W. (2014). Pengaruh Kepemilikan Manajerial Dan Kepemilikan Institusional Pada Nilai Perusahaan. E-Jurnal Akuntansi 9(3): 575-90.

Dhani, I. P., \& Utama , A. A. G. S. (2017). Pengaruh Pertumbuhan Perusahaan, Struktur Modal, Dan Profitabilitas Terhadap Nilai Perusahaan. Jurnal Riset Akuntansi dan Bisnis Airlangga 2(1): 135-48.

Gitman, L. J., \& Zutter, C. J. (2015). Financial Management Principles of Managerial Finance (Global Edition).

Gustian, D. (2017a). 2635-5315-1-Sm. Pengaruh Pertumbuhan Perusahaan, Keputusan Investasi, Dan Keputusan Pendanaan Terhadap Nilai Perusahaan 5: 2635-5315.

Gustian, D. (2017b). Pengaruh Pertumbuhan Perusahaan, Keputusan Investasi, Dan Keputusan Pendanaan Terhadap Nilai Perusahaan (Studi Empiris Pada Perusahaan Manufaktur Yang Terdaftar Di Bursa Efek Indonesia 2010-2014). Jurnal Akuntansi. 3(2): 84-100.

Izza, I. (2013). Pengaruh Kebijakan Utang, Pertumbuhan Perusahaan Dan Profitabilitas Terhadap Nilai Perusahaan (Studi Kasus Pada Perusahaan Jii Tahun 2011-2013). Uin Malang.

Kusumajaya D.K. (2011). Pengaruh Struktur Modal Dan Pertumbuhan Perusahaan Manufaktur Di Bursa Efek Indonesia. Akuntansi.

Lasmita, O. N., \& Susanti. (2016). Pengaruh Struktur Modal, Pertumbuhan Perusahaan, Profitabilitas, Dan Kebijakan Dividen Terhadap Nilai Perusahaan Studi Pada Emiten Sektor Manufaktur Di Bei. Agustus 7(2): 4353.

Murnita, P. E. M., \& Putra, I M. P. D. (2018). Pengaruh Corporate Social Responsibility Terhadap Nilai Perusahaan Dengan Profitabilitas Dan Leverage Sebagai Variabel Pemoderasi. E-Jurnal Akuntansi 23: 1470.

Santi, P. M. K. M., \& Novita H. (2007). Studi Kasus Pada Sektor Industri Food And Beverages.

Sri, A., Mahatma D., \& Wirajaya, A. (2013). Pengaruh Struktur Modal, Profitabilitas Dan Ukuran Perusahaan Pada Nilai Perusahaan. E-Jurnal Akuntansi 4(2): 358-72.

Suastini, N. M., Purbawangsa, I. B. A. \& Rahyuda, H. (2016). Pengaruh Kepemilikan Manajerial Dan Pertumbuhan Perusahaan Terhadap Nilai Perusahaan Pada Perusahaan Manufaktur Di Bursa Efek Indonesia (Struktur Modal Sebagai Variabel Moderasi). E-Jurnal Ekonomi dan Bisnis Universitas Udayana 5(1): 143-72.

Sumiati, D. A. F. (2013). Analisis Kinerja Keuangan Bank Dengan Menggunakan CAMEL Periode 2010-2012. Fakultas Ekonomi dan Bisnis, Universitas Brawijaya.

Suwardika, I, \& I Mustanda. 2017. Pengaruh Leverage, Ukuran Perusahaan, Pertumbuhan Perusahaan, Dan Profitabilitas Terhadap Nilai Perusahaan Pada Perusahaan Properti. None. 